\title{
Motivation to Learn and Distance Learning Programs: What Brazilian Workers Think about?
}

\section{Francisco Antonio Coelho Junior ${ }^{1,2}$, Mariana Carolina Rêgo'2, Mariane Cortat de Melo², Natasha Fogaça ${ }^{2}$, Alan Rodrigues da Silva², Pedro Paulo Teófilo Magalhães de Hollanda ${ }^{2,3}$, Cristiane Faiad4,5,6, Wilsa Maria Ramos ${ }^{4,7}$}

${ }^{1}$ Departament of Management, University of Brasília, Brasília, Brazil

${ }^{2}$ Post-Graduate in Management (FACE/PPGA), University of Brasília, Brasília, Brazil

${ }^{3}$ National School of Public Administration (ENAP), Brasília, Brazil

${ }^{4}$ Institute of Psychology (IP), University of Brasília, Brasília, Brazil

${ }^{5}$ Departament of Social and Work Psychology (PST), University of Brasília, Brasília, Brazil

${ }^{6}$ Social, Organizational and Work Psychology (PSTO), University of Brasília, Brasília, Brazil

${ }^{7}$ Departament of Scholar and Development Psychology (PED), University of Brasília, Brasília, Brazil

Email: fercoepsi@gmail.com, acoelho@unb.br

How to cite this paper: Junior, F. A. C., Rêgo, M. C., de Melo, M. C., Fogaça, N., da Silva, A. R., de Hollanda, P. P. T. M., Faiad, C., \& Ramos, W. M. (2016). Motivation to Learn and Distance Learning Programs: What Brazilian Workers Think about? Creative Education, 7, 2576-2596. http://dx.doi.org/10.4236/ce.2016.717243

Received: October 5, 2016

Accepted: October 31, 2016

Published: November 3, 2016

Copyright $\odot 2016$ by authors and Scientific Research Publishing Inc. This work is licensed under the Creative Commons Attribution International License (CC BY 4.0).

http://creativecommons.org/licenses/by/4.0/ (c) (i) Open Access

\section{Abstract}

Distance education encompasses all forms of learning and teaching in which those who learn and who teach are in different locations. It involves the separation of teachers and learners which distinguishes it from face-to-face education. Online education is characterized by the influence of an educational organization which distinguishes it from self-study and private tutoring. Organizations are both consumers and suppliers of distance education because of its benefits such as productivity improvements and cost savings in training. This paper aims to identify the motivational profile to learning by distance education students who work in a national Brazilian Organization. We consider that the participation in distance learning programs is motivator of stay work. We applied a Brazilian questionnaire (17 item) to 127 employees (majority were male 97.60\%, in the range 26 - 33 years and 6 to 10 years of time of service in the Organization) who were enrolled or who had taken any course in distance modality in the last 2 years. The results indicate that there is a relatively negative participants' perception about how distance-learning programs can add to their performance in terms of skills and competences acquisition. The support of colleagues is very important for learning and its impact at work organizational routines. 


\section{Keywords}

Motivation to Learning, Reflective Learning, Transformative Education, Distance Education, Distance Learning

\section{Introduction}

Distance education is a modality of learning that is in expansion in recent times. This type of education, offered mainly by internet, has as a fundamental premises democratizing education and promoting social inclusion. To the learner, open and distance learning means more freedom of access, and thereby a wider range of opportunities for learning and qualification.

Two main factors have led to an explosion of interest in distance learning: the growing need for continual skills upgrading and retraining; and the technological advances that have made it possible to teach more and more subjects at distance. The increasing number of open universities being established across the world is highly indicative of this trend.

The basic premise of distance education is to eliminate geographical barriers, facilitating full and unrestricted access to knowledge at any time (Gasevic, Kovanovic, Joksimovic, \& Siemens, 2014). What can be observed, moreover, is that such learning isn't applicable to all kinds of student (Baghdadi, 2011). Distance learning assumes some characteristics such as motivation to study, personal interest, commitment, autonomy, self-direction and management of own learning strategies. This requires an active role of student in relation to their knowledge construction and autonomy (Chen, Magoulas, \& Dimakopoulos, 2005; Riding \& Sadler-Smith, 1997).

The student needs to "learn to learn" through distance education (Norasmah, Mohd, \& Hasril, 2010). A simple modification of a traditional and classic formal education environment to the innovative environment of distance learning isn't easy, and it's an additional challenge. The student should be able to study independently, without the physical presence of the teacher as a facilitator of learning. The rapid development of Information and Communication Technologies (ICTs) and the move towards more knowledge-intensive, interdependent and internationalized societies create new challenges and opportunities for the design and delivery of education.

In this context, strategies and learning processes become fundamental question in its full success. Distance learning should be meaningful to the student's eyes, taking transformative nature (Fleming \& Baume, 2006). Thus, it's necessary to implement environments and/or teaching methodologies that facilitate learning (Lloyd \& Robertson, 2012) and are not restricted only to full access to information. The excess of information can make the student feel lost, isolated, and their learning be negative impacted. The student may even feel unmotivated, making his poor learning.

Therefore, the present study aims to identify the motivational profile to learning by distance education students who work in a Brazilian Organization. More specifically, 
we want investigate how Brazilian workers who study at a distance way realize the philosophy of distance education, and the perception of the effectiveness of the instructional design and procedures related to their individual performance at work. It is intended to discuss how, in fact, students perceive their learning as significant, emphasizing its integrative character.

The research question is: considering the expansion and ease of access to distance learning programs, which is the motivational profile of Brazilian workers students regarding the characteristics of distance education? As secondary questions: how to ensure that these students will succeed in their learning? How to reduce the high evasion rates of those who study the distance? How to ensure that they do not give up on the way? How to deal with the frustrations and difficulties encountered by them? Is simply promoting opportunities of access to distance learning programs enough? How the participation in distance learning programs will motivate for their continuous learning in the work environment? We consider here that the participation in distance learning programs is a motivator of employee intention to stay (working for the company).

We hope to demonstrate the importance of student distance learning development to critical thinking, ability to learning at all times and discipline. The profile of online students also needs to consider their motivation to learn and organizational commitment. What motivates a student to join an online program? We will highlight that the student should be autonomous and has an active role in the construction of their knowledge.

\section{Theoretical Framework}

\subsection{Distance Learning}

The distance learning context has become a recurrent locus of empirical research, especially from the 2000s, with the consolidation of the internet as a communication tool (Bozkurt, Akgun-Ozbek, Yilmazel, Erdogdu, Ucar, Guler, Sezgin, \& Aydin, 2015). Frameworks from Education, Psychology and Health can be found on the study of variables related to distance education. The focus of research rests mainly over the impact of distance learning technologies or the professional and personal experiences in distance education or distance learning contexts. According to Jong (2010), theoretical and methodological aspects are being considered in research on distance education, especially: the role of social actors involved (tutors and students), quality of the content offered, aspects relating to the planning and delivery of content, performance monitoring strategies, student assessment and operational logistics.

Specifically considering the Brazilian empirical scenario, research involves the use of case studies, with a qualitative/quantitative approach, concentrating on understanding the impact of support technology and the learning environment. The aim of the researches seems to be more related to the analysis of the development and impact of new technologies than to pedagogical practices. According to Hew and Cheung (2014), most studies have more local coverage than global, limited to the specific contexts in which they emerged without identifying innovative strategies and success factors that are related to the good e-learning practices. 
For Jacoby (2014), recent empirical findings have emphasized the learning processes utilized by students, focusing on metacognition. Some questions discussed are: how the student learning? What kind of strategies he uses? Metacognition facilitates the acquisition of knowledge, considering the self-knowledge of the student about his own learning process. Metacognition can foster awareness of learning processes adopted by learners, such as selecting the most appropriate learning strategies to carry out certain tasks and monitoring the implementation of these strategies considering the learning objectives.

Factors affecting the efficiency of distance learning systems include: the number of learners enrolled, the size of the curriculum, technology choice, the level of student support and a range of working, labor market and structural practices (Veletsianos \& Sheperdson, 2016). Research is focused on methodologies and teaching-learning tools. Little significant research was development about personal characteristics of the learners and their needs (Jordan, 2014). Knowledge about the learning difficulties encountered by learners allows institutions verify their needs, developing, for example, instructional programs that enhance the learning and success in academic education. It's essential to map the motivation of the learner, identify his degree of commitment and participation (Kennedy, 2014).

The actions of distance education aim to create opportunity to broaden access to knowledge as well as flexibility, and to optimize teaching and learning process (Bulfin, Pangrazio, \& Selwyn, 2014). Innovative trends of continuing education adopt formal education practices in the context of open distance education programs. Technological advances in the world have enabled organizations to make significant investments in training programs in distance education modality. Corporate universities have disseminated new knowledge and professional competences through training actions remotely by intra or internet.

For O'Connor (2014), the advent of distance education programs allowed an increase in the quality and efficiency of education systems. It facilitates the access to the recycling of people's knowledge and competences. Perna, Ruby, Boruch, Wang, Scull, Ahmad, \& Evans (2014) consider distance learning programs educational a powerful tool with central features such as availability, flexibility and student autonomy, emphasizing the need for the adequate use of technology (use of multimedia) in education.

Dirr (2003) raised the following questions: who are, effectively, the learners and customers of distance education programs? What are their real needs and aspirations? How distance education can overcome obstacles in terms of opportunities access and logistics in relation to traditional education? What is the real value and importance of technology in distance education? How the quality of education provided can be measured and validated? What is the empirical evidence that students of distance education have the necessary access to all possibilities covered by distance education programs? How can we adapt different learning styles and strategies in general standards of distance education programs? Anyway, these issues characterize the reality of all those involved in distance education, being necessary reflections and research on every point 
here raised.

For Gasevic, Kovanovic, Joksimovic, \& Siemens (2014) and Bowen and Ithaka (2012), the distance education has become important as a teaching and learning system in organizations, because most of them joined to the teaching distance programs. The authors point out some essential characteristics of distance education: complexity, dynamism and emphasis on the independence of the student in their learning.

Hanna (2003) presents some difficulties associated to this kind of modality of learning, such as the tutor-student relationship and the definition of what is, effectively, learning. Note the focus on the perspective of constructivist learning, with the center of attention on the exploration of study content by the student, proactively interacting with teacher and colleagues.

Bozkurt et al. (2015) points that distance students have higher needs for educational support than students in traditional contexts of learning. For this reason, distance education programs seek to consolidate administrative infrastructure and guidance services, providing support and constant monitoring. Bulfin, Pangrazio and Selwyn (2014) state that distance education needs to be planned not only on teaching processes (organizational structure, planning and methodologies, for example), but also considering the learning processes, such as identifying characteristics and needs of students, their motivation, styles and strategies of learning and the environmental conditions to learn.

Brown and Liedholm (2004) refer to breaking barriers of time and space as essential to distance education. It covers the use of new technologies, adapted to their own teaching strategies focused on independence and autonomy of the learner. Hoic-Bozic, Mornar and Boticki (2009) point out the following characteristics: conditions and access facilities; optimizing the cost benefit ratio; teaching and learning more flexible; constant interaction (including between student and the content); speed and adaptation of new knowledge when needed (adequacy content).

In the context of formal work organizations, it's used the term 'training offered by distance programs'. The concepts of distance education and training are related, but not identical. In this case, distance training would be aimed at improving the performance of the learner aligned to the organization's needs, instead of distance education, not necessarily restricted to the boundaries of organizations.

Training programs aim to develop organizational competences in order to improve the performance of social actors in accordance with organizational goals and demands. The training programs are most employed in instructional systems planned within organizations, focused on the specific acquisition of competences by identifying training needs, instructional planning and execution. The possibility of training a large number of people at the same time, and the need to fill gaps in the employees' competences, promoting more accurate performance, justify the adoption of these programs in formal work organizations.

Oblinger and Rush (2003) justify the need for implementation of distance education programs under the same optimal cost-effective comparison to the adoption of classroom training programs. Thus, and according to Watkins and Kaufman (2003), the or- 
ganization would design the organizational processes and work routines toward distance education. However, the innovation of the proposal and teaching methodology distance can have culturally constructed barriers and shared among individuals. Among these barriers, some perceptions that the classes must comply with formal education and learning systems, with the physical presence of teachers and classmates in the same space at the same time for learning to occur.

Hanna (2003) points out that distance learning programs are capable of causing deep changes in work procedures. Technological changes and structural/systemic changes in organizations (re-orientation purposes and nature of the task) must be necessary. The distance education would facilitate more effective implementation of work routines, because promote quickly learning necessary for a large amount of employees.

Watkins and Kaufman (2003) consider the following steps for effective implementation of distance learning in organizations: identification and alignment of vision and organizational goals to distance learning programs; identification of distance education implementation needs; mapping critical resources to the successful implementation of the system (for example, evaluate the expected performance of context identified by a problem situation), and identify possible solutions and alternative solutions considering a set of alternatives. The authors discuss also the need for analysis of the organizational structure and planning for effective implementation of distance education. The authors propose a rigorous necessity assessment (strategic planning, tactical and operational), specifically focused on distance education, maximizing its implementation.

Distance education programs probably will encounter significant cultural obstacles to its effective implementation, especially within public organizations (more bureaucratized). There are a lot of research possibilities in terms of the efficacy of the planning, access opportunities, and also know-how, especially how best to provide distance learning avoiding misunderstandings considering the simple transposition of a traditional teaching model to a model of distance learning.

Efforts have been made to expand the distance beyond the boundaries of traditional schools. Much has been researching the use of resources of open learning in the context of work organizations. According to Zawacki-Richter, Bäcker, \& Vogt (2009), there is already consolidation of distance education as an important mode of teaching and learning in the training and development of individuals. The concern in the study of distance education in the context of work is the analysis of related variables that make distance learning collaborative tool, with great interaction between students and tutors, maximizing the social construction of learning opportunities. Thus, it is noted that the expansion of access to distance education is essential to its consolidation as a new teaching and learning tool in the context of work organizations (Stanton \& Harkness, 2014).

\subsection{Motivation at Work and Motivational Profile}

Much empirical research on the organizational field was developed on motivation (Guerrero, Lapalme, \& Seguin, 2015; Meyer, Stanley, Herscovitch, \& Topolnytsky, 2002). Theories of work motivation investigate variables related to understanding the 
intrinsic factors (cognitive, personality traits, psychological rewards, responsibility and recognition) and extrinsic (tangible rewards such as wages, rewards and working conditions) to the individuals.

According to Gagné and Deci (2005), motivation surges in the individual, and depends on of the influence of external factors. These factors can stimulate the achievement of motivated behaviors. The influence of managerial leadership styles on motivation (e.g. McMurray, Pirola-Merlo, Sarros, \& Islam, 2010; Nijstad, Berger-Selman, \& De Dreu, 2012; Walumbwa, Avolio, Gardner, Wernsing, \& Peterson, 2008; Yang \& Mossholder, 2010) and the role of the support provided by colleagues and the working group in generating motivation are the most commonly search topics (Korek, Felfe, \& Zaepernick-Rothe, 2010).

Motivation can be understood as the energy responsible for the intensity, direction and persistence of the efforts of a person to achieve a certain goal (Grant \& Sumanth, 2009).

The requirements establish the intensity and direction of human motivation and the expectations are responsible for the persistence of motivated behavior. The need or personal goal generates motivation. The motivation is reflected in a behavior whose direction and persistence will depend on the expectations related to how their behavior will contribute to the achievement of this need. Establish a motivational profile is not an easy task, especially considering that the origins of individual motivation are very different (what motivates one person not always motivates other).

According to Vroom (1964) the need of social acceptance becomes an important motivational factor to the conduct individuals' behaviors. For Wendelien \& Henk (1996), the "content theories" treat identify key constructs giving rise to human activity, and therefore, labor activity, having on human needs as construct used in these theories. The 'process theories' aims to understand and explain the motivational process that determines the direction and persistence of behavior, with the expectation of the most prominent constructs this approach (Vroom, 1964).

For Hackman and Oldham (1976), motivation can be derived from the following factors like variety and identity with the job activities. The meaning of work, autonomy and feedback are important too. Skills, identity with the task and work meaning represent personal or dispositional characteristics. Perception of autonomy and feedback refer to environmental variables.

Cognitive theories of work motivation based on the premise that employees make their choices based on their beliefs, needs and expectations (rational choice) in a logical sequence, thus, arises the assumptions of the theory of equity, in which the perception of injustice creates cognitive dissonance and consequent demotivation. This may have a deeply negative impact on job performance.

The Theory of Expectancy of Vroom is one of the theories most applied today. This theory has three dimensions are as follows:

a) Valency (effort-performance)-degree of effort required to achieve the results from the value attributed by the individual to a particular object. Theory compatible 
with this dimension is the theory of goal setting.

b) Expectancy (performance-reward) - how the individual' believes that the performance achieved will lead to the desired result. The theory of cognitive evaluation can influence this dimension.

c) Instrumentality (reward-personal goals) - how much organizational rewards satisfy personal goals. This dimension recognizes the professional and personal interests as a form of motivation.

To Steers, Monday and Shapiro (2004), the dimensions mentioned above are not independent, but interrelated. There is no default, and the effort to achieve great results is directly related to the perception of reward to be received. The need is the greatest force that generates the impulse for motivation. Expectations determine the persistence to achievement of motivated behavior.

Relating more directly with this work, we believed that distance training programs is able to generate a particular value to the individual, because it serves as a tool or instrument for achieving other results he expects and values, as expected promotion or salary increase. It's urgent, therefore, understanding the individual needs, beliefs and expectations, once the motivation in the execution of organizational tasks depends on how this effort is necessary for employees to meet their personal desires.

Therefore, organizational policies should try to balance individual interests with the interests and demands of the organization. Would not be the distance learning programs a way to allow the learner to create a stimulus to pursue their individual interests within the organization, and this promote superior performance?

\section{Method}

\subsection{Organization Characterization}

The Organization researched was a Brazilian military public institution. Its mission concerns the guarantee of Brazil national security, and maintenance of law and order. This Organization provides its employees access to distance education programs in different areas of knowledge. Because of distance learning programs, individuals can study in this far way places. The Organization provides a very strong support to the development of their employees, especially for those who are working constantly on missions.

\subsection{Sample}

The total sample was of 127 employees enrolled or who had taken any course in distance mode in the last 2 years. This sample was not probabilistic, but intentional, purposeful, by accessibility or typicality.

It was found that, of the 127 participants, the great majority were male $(97.60 \%)$, the majority of respondents (50.4\%) are in the range 26 - 33 years and most respondents $(44 \%)$ is in the range of 6 to 10 years of time of service in the Organization.

The functions performed, categorized in "Personal Assistant Area", "Finances Area", "Material Area", "Public Relations Area", "Computers Area”, "Bidding and Purchases Areas" and "Legal Advice". Table 1 summarizes the sample profile. 
Table 1. Sample profile.

\begin{tabular}{|c|c|c|}
\hline Variables & Absolute frequency & Relative frequency \\
\hline \multicolumn{3}{|l|}{ Gender } \\
\hline Male & 124 & $97.60 \%$ \\
\hline Female & 3 & $2.40 \%$ \\
\hline Total & 127 & $100 \%$ \\
\hline \multicolumn{3}{|l|}{ Age } \\
\hline from 18 to 25 years & 25 & $20.20 \%$ \\
\hline from 26 to 33 years & 64 & $50.40 \%$ \\
\hline from 34 to 41 years & 18 & $14.50 \%$ \\
\hline from 42 to 49 years & 20 & $16.10 \%$ \\
\hline Total & 127 & $100 \%$ \\
\hline \multicolumn{3}{|l|}{ Time of service } \\
\hline from 1 to 5 years & 29 & $23.00 \%$ \\
\hline from 6 to 10 years & 44 & $35.00 \%$ \\
\hline from 11 to 15 years & 18 & $14.00 \%$ \\
\hline from 16 to 20 years & 13 & $10.00 \%$ \\
\hline over 20 years & 23 & $18.00 \%$ \\
\hline Total & 127 & $100 \%$ \\
\hline \multicolumn{3}{|l|}{ Job function } \\
\hline - HR assistant & 50 & $39.40 \%$ \\
\hline - Finance assistant & 16 & $12.60 \%$ \\
\hline - Store keeper & 28 & $22.00 \%$ \\
\hline - PR assistant & 12 & $9.40 \%$ \\
\hline - IT assistant & 13 & $10.20 \%$ \\
\hline - Procurement assistant & 4 & $3.10 \%$ \\
\hline - Legal office management assistant & 4 & $3.10 \%$ \\
\hline Total & 127 & $100 \%$ \\
\hline
\end{tabular}

\subsection{Characterization of the Instrument}

A fully Brazilian structured questionnaire, constructed from analysis of the literature containing the main dimensions of motivation that could be applied to the understanding of the specific object of study (distance learning programs), was applied. We identified, in the international empirical literature of distance education applied to work context, motivation categories applied specifically to distance education. Currently this questionnaire is in statistical validation progress in a big Brazilian sample.

From these theoretical categories, 23 items were developed for evaluation in a Brazilian context by judges $(\mathrm{N}=5)$, who were teachers of the Department of Management at the University of Brasilia, and semantic validation, with 4 managers of the Organization in this study.

The final questionnaire contained 17 randomly presented statements, associated to a 5 points Likert scale, anchored in the following variations: 1) I strongly disagree; 2) I partially disagree; 3) I am indifferent; 4) I partially agree and 5) I totally agree. The statements sought to verify the perception of respondents on the following aspects or theoretical dimensions, as shown in Table 2.

We added to the questionnaire a self-report item about performance, asking the respondent attributed a score from 0 (zero) to 10 (ten) for their performance at work 
Table 2. Questionnaire theoretical dimensions.

\begin{tabular}{|c|c|c|c|}
\hline Item & Dimensions & Theoretical dimension definition & $\begin{array}{l}\text { Relation between the dimension and the } \\
\text { "motivational profile" construct }\end{array}$ \\
\hline $2,3,7,10$ and 15 & Support & $\begin{array}{l}\text { Importance and relevance of organizational support for } \\
\text { employees to enroll in distance education programs }\end{array}$ & $\begin{array}{l}\text { Verify the relation between organizational } \\
\text { support and employee motivation }\end{array}$ \\
\hline $4,5,8$ and 13 & Expectation & $\begin{array}{l}\text { Expectations towards the course, according to Vroom } \\
\text { Expectancy Theory (1964) }\end{array}$ & $\begin{array}{l}\text { Verify the relation between employee's expectation } \\
\text { towards distance courses as a motivation factor }\end{array}$ \\
\hline 6,9 and 14 & Recognition & Group recognition & Verify group social acceptance as a motivation factor \\
\hline $1,11,12$ and 17 & Reliability & $\begin{array}{l}\text { Employee/student importance attribution to distance } \\
\text { courses reliability }\end{array}$ & $\begin{array}{l}\text { Verify whether online education can be considered } \\
\text { as an employee demand }\end{array}$ \\
\hline 16 & $\begin{array}{l}\text { Job design } \\
\text { enrichment }\end{array}$ & Job design enrichment & $\begin{array}{l}\text { Verify if employee's activities are related to the skill } \\
\text { and knowledge acquired after the course }\end{array}$ \\
\hline
\end{tabular}

considering the last six months. We want to correlate the perceptions of distance education programs as a source of motivation to work and the perception of the performance in the last 6 months.

\subsection{Procedures of Data Collection and Analysis Data}

The questionnaire was applied in person or by electronic interface, via e-mail, or providing a link to the survey on social networks, blogs and others. We used "google docs" platform.

Respondents received an e-mail with some initial guidelines and the link to access the survey. They should read and simply click and access the full questionnaire. Respondents agreed to participate in the survey from the acceptance of prior consent. The responses of the participants were being tabulated in a database. There were no questionnaires filled out incompletely, the tool only saved the data when all items have been filled. The data collection time was 30 days.

Data were tabulated and categorized, and was made descriptive statistical analysis using the SPSS (Statistical Package for Social Sciences), version 18.0. The measures of central tendency (mean and standard deviation), and the correlation coefficients were calculated. The results can be seen below.

\section{Results}

The results will be presented considering each dimension of research in analysis, namely: "Support", "Expectation”, “Recognition”, "Reliability" and "Job Design Enrichment". Later, we will present data analysis on performance obtained through employees' self-report, regarding perceived performance in the last six months. Finally, spearman bivariate correlations among the evaluated dimensions are presented.

In general, the results indicate that the participation in distance learning course offered motivates employees. Work context and psychosocial support provided by the organization is critical to the achievement of the course objectives. The transfer climate, especially provided by colleagues, is essential. 


\subsection{Support Dimension}

The support dimension relates to how an employee perceives the organizational support for the learning and application of knowledge acquired by distance education programs. We identified a discrepancy in the perception of respondents regarding the effectiveness of the support provided by the management and Organization. The item " $M y$ organization creates real conditions to engage in distance courses if I am interest$e d$ " has the bigger mean $(\mathrm{M}=2.87 ; \mathrm{SD}=1.18)$. The standard deviations were relatively high, indicating heterogeneity or divergence of opinions, requiring further analysis of each item.

The disagreement frequencies were higher than the agreement in relation to the support provided by the organization and leadership (see Table 3). The high standard deviations indicate that this perception changes when considering the work environment to which the individual performs his duties. There is not a very favorable perception of employees on the support provided by the Institution. The data are shown in Table 3.

According to Table 3, research participants do not perceive the organizational support offered as favorable. There has not been a direct influence of this dimension as a motivational factor. The rigidity of the organizational structure, militarized, with an organizational culture of deference and unrestricted compliance with organizational values may be an explanation for this finding. The support of managers is based on the task, not personal or emotional factors.

\subsection{Expectancy Dimension (Vroom, 1964)}

The perception of employees regarding their personal and professional expectations, related with the completion of courses in distance education mode, presented greater homogeneity in respondents opinion. The valence can be regarded as positive. The vast majority of employees agree that their efforts in completing the course in the distance modality can be translated into higher performance, since the knowledge acquired in the course tend to make tasks easier. If there were support this valence attributed to distance learning courses could hypothetically still be higher.

It's noteworthy that the valence refers to the relationship between the effort or action to do a distance learning course and this lead to the achievement of a performance. The

Table 3. Frequencies and percentage per item for the organizational support dimension.

\begin{tabular}{ccccccccccc}
\hline & \multicolumn{2}{c}{ Strongly disagree } & \multicolumn{2}{c}{ Partially disagree } & \multicolumn{2}{c}{ Neutral } & \multicolumn{2}{c}{ Partially agree } & \multicolumn{2}{c}{ Strongly agree } \\
\cline { 2 - 11 } Items & F & F\% & F & F\% & F & F\% & F & F\% & F & F\% \\
\hline 2 & 15 & 10.8 & 40 & 31.5 & 32 & 25.2 & 27 & 21.3 & 13 & 10.2 \\
3 & 36 & 28.3 & 24 & 18.9 & 21 & 16.5 & 22 & 17.3 & 24 & 18.9 \\
7 & 38 & 39.9 & 36 & 28.3 & 26 & 20.5 & 18 & 14.2 & 9 & 7.1 \\
10 & 36 & 28.3 & 29 & 22.8 & 35 & 27.6 & 14 & 11 & 13 & 10.2 \\
15 & 50 & 39.4 & 34 & 26.8 & 20 & 15.7 & 15 & 11.8 & 8 & 6.2 \\
\hline
\end{tabular}


Expectancy refers to how much this performance leads to a reward within the company or institution. Instrumentality means how much the reward is compatible with the personal goals of the employee. According to Expectancy Theory by Vroom (1964), the item has the bigger mean is "When I am capacitated through distance learning courses, some tasks become easier to be done" $(\mathrm{M}=4.10, \mathrm{SD}=1.13)$.

The expectation about the possibility of enrolling in distance learning course appears to be favorable, according to the results obtained. The high standard deviations confirmed also that there is discrepancy in the judgment of the participants. With respect to instrumentality (item 5), it appears that the usefulness of the courses, in terms of its application in the work environment, has been well designed by the managers of the Organization. It seems that the participants of this study find that taking a distance learning course is effectively advantageous within the organization investigated. With this, they feel motivated.

Observing the items distributed in three dimensions of the theory of expectation, Vroom (1964) notes that the item 8, unlike the others, resulted in a less favorable perception of the research sample, tending to the disagreement to indifference.

Employees consider that the practice of distance education in the context of Organization doesn't enable the execution of their own goals. Motivation based on the model of Expectancy Theory is fully achieved with the realization that your personal goals are effectively achieved, what seems to be not happening. Descriptive frequency analysis, presented in Table 4, confirms these assertions.

\subsection{Social Recognition Dimension}

It's observed a favorable behavior of colleagues to the learner who studies in the distance education modality. Recognition of the social group is fundamental dimension motivating the learner. It legitimizes their effort expended and it feels valued, pledging more. The own social group may support the student in making its most significant and transformative learning.

Questions may be discussed informally, and informal learning strategies may emerge from this social interaction. The item has the bigger mean was "In this organization, those enrolled in distance learning courses are well seen by teammates" $(\mathrm{M}=3.59 ; \mathrm{SD}=$ $0.85)$.

The results shown in Table 5 suggest that peer support is indeed fundamental to the realization distance learning courses within the Organization investigated.

Table 4. Frequencies and percentage per item for the employee expectancy dimension.

\begin{tabular}{ccccccccccc}
\hline & \multicolumn{2}{c}{ Strongly disagree } & \multicolumn{2}{c}{ Partially disagree } & \multicolumn{2}{c}{ Neutral } & \multicolumn{2}{c}{ Partially agree } & \multicolumn{2}{c}{ Strongly agree } \\
\cline { 2 - 11 } Items & F & F\% & F & F\% & F & F\% & F & F\% & F & F\% \\
\hline 4 & 10 & 7.9 & 6 & 4.7 & 27 & 21.3 & 29 & 22.8 & 55 & 43.3 \\
5 & 6 & 4.7 & 7 & 5.5 & 18 & 14.2 & 33 & 26 & 63 & 49.6 \\
8 & 14 & 11 & 17 & 13.4 & 59 & 46.5 & 36 & 28.3 & 1 & 0.8 \\
13 & 5 & 3.9 & 17 & 13.4 & 29 & 22.8 & 41 & 32.3 & 35 & 27.6 \\
\hline
\end{tabular}


Social incentives, such as praise, for example, are important motivational factors. There is no form of sanction or social rejection directed at those who make courses in distance education modality in the organization.

\subsection{Reliability Dimension}

This dimension relates to the importance perceived by the employee regarding the provision of courses in distance education modality. The participants of this study agree homogeneously that participate of distance learning programs is very important and depends directly on the motivation of the student considering his recognition of favorable working environment conditions.

Good reputation is a factor that reduces discrimination on who does courses in the distance. When an employee is a learner in a distance learning course, we can infer that this organization believes the course tends to provide necessary competences that it will be apply at work. If training was based on learning needs assessment probably your application will happen deeply.

It is possible to conclude that respondents, without the opportunity to transfer the contents, would feel less motivated to work. The item has the bigger mean is "For me, it is important that the organization encourages its employees to engage in distance learning courses, when related to their tasks" $(\mathrm{M}=4.64 ; \mathrm{SD}=0.69)$. These courses contents bring learning opportunities and impact on labor routines. The results allow us to affirm that the practice of distance education in the organization under study is a motivational factor.

The data showed in Table 6 also suggest that the motivation to study in the distance modality is intrinsic, and considers the need for continuous learning at work.

Table 5. Frequencies and percentage per item for social recognition dimension.

\begin{tabular}{ccccccccccc}
\hline & \multicolumn{2}{c}{ Strongly disagree } & \multicolumn{2}{c}{ Partially disagree } & \multicolumn{2}{c}{ Neutral } & \multicolumn{2}{c}{ Partially agree } & \multicolumn{2}{c}{ Strongly agree } \\
\cline { 2 - 11 } Items & F & F\% & F & F\% & F & F\% & F & F\% & F & F\% \\
\hline 6 & 1 & 0.8 & 8 & 6.3 & 52 & 40.9 & 47 & 37 & 19 & 15 \\
9 & 6 & 4.7 & 39 & 26.8 & 45 & 35.4 & 24 & 18.9 & 18 & 14.2 \\
14 & 0 & 0 & 23 & 18.1 & 42 & 33.1 & 38 & 29.9 & 24 & 18.9 \\
\hline
\end{tabular}

Table 6. Frequencies and percentage per item for reliability dimension.

\begin{tabular}{ccccccccccc}
\hline & Strongly disagree & \multicolumn{2}{c}{ Partially disagree } & Neutral & \multicolumn{2}{c}{ Partially agree } & \multicolumn{2}{c}{ Strongly agree } \\
\cline { 2 - 10 } Items & F & F\% & F & F\% & F & F\% & F & F\% & F & F\% \\
\hline 1 & 0 & 0 & 2 & 1.6 & 9 & 7.1 & 22 & 17.3 & 94 & 74 \\
11 & 0 & 0 & 18 & 14.2 & 32 & 25.2 & 42 & 33.1 & 35 & 27.6 \\
12 & 0 & 0 & 19 & 15 & 49 & 38.6 & 29 & 22.8 & 30 & 23.6 \\
17 & 0 & 0 & 2 & 1.6 & 46 & 36.2 & 36 & 28.3 & 43 & 33.9 \\
\hline
\end{tabular}




\subsection{Job Design Enrichment Dimension}

With regard to this dimension, a relatively negative perception it appears from participants on how a distance learning course can add to their performance in terms of skills and competences acquisition. Only one item makes up this dimension. Its average $(\mathrm{M}=$ 2.54) and high standard deviation $(\mathrm{SD}=1.38)$ also demonstrates heterogeneity in the perception of the participants.

It's assumed that employees don't realize they are encouraged to apply their skills and expertise acquired in the course of their work routines. From the above, it can be deduced that this dimension in question is not perceived as a motivating factor. The culture of the organization, militarized, impedes the notion of autonomy and freedom in the execution of organizational routines. There is a belief that the impact of learning on the job could increase the motivation of employees since there were aspects of the variety of competences, task identity, autonomy and continuum feedback. The data in Table 7 illustrate this finding.

\subsection{Performance Self-Report at Work}

The respondents attributed a score from 0 (poor performance) to 10 (excellent performance) related to its performance at work the past six months, in order to compare the perception of distance education as a source of motivation and self- evaluation of the performance. Descriptive results can be seen in Table 8.

The results suggest that participants tend to self-evaluate positively. This result can be considered important especially considering the expected alignment between the

Table 7. Frequencies and percentage per item for job design enrichment dimension.

\begin{tabular}{ccccccccccc}
\hline & \multicolumn{2}{c}{ Strongly disagree } & \multicolumn{2}{c}{ Partially disagree } & \multicolumn{2}{c}{ Neutral } & \multicolumn{2}{c}{ Partially agree } & \multicolumn{2}{c}{ Strongly agree } \\
\cline { 2 - 11 } Item & F & F\% & F & F\% & F & F\% & F & F\% & F & F\% \\
\hline \multirow{2}{*}{16} & 46 & 36.2 & 13 & 10.2 & 34 & 26.8 & 22 & 17.3 & 12 & 9.4 \\
\hline
\end{tabular}

Table 8. Performance self-reports by learners.

\begin{tabular}{|c|c|c|}
\hline Scores & Frequency & Percentage \\
\hline 2 & 1 & $0.8 \%$ \\
\hline 5 & 6 & $4.7 \%$ \\
\hline 6 & 5 & $3.9 \%$ \\
\hline 7 & 15 & $11.8 \%$ \\
\hline 8 & 31 & $24.4 \%$ \\
\hline 9 & 43 & $33.9 \%$ \\
\hline Superior performance & 26 & $20.5 \%$ \\
\hline $\mathrm{N}$ & 127 & $100 \%$ \\
\hline Average & \multicolumn{2}{|c|}{8.36} \\
\hline Std. deviation & \multicolumn{2}{|c|}{1.42} \\
\hline
\end{tabular}


courses offered in the distance modality and its subsequent impact on performance; distance learning courses can be developed as a valid tool to improve professional performance at work.

The modality of distance education programs in the context investigated can be considered as a motivating factor to stay in the Organization. The recognition by the participants about the organizational support provided to the practice of distance education is crucial. Supervisors and colleagues need to develop explicit behavior support learning. The perception of applicability of the course is motivating the learner who needs to recognize clearly favorable conditions for their learning and subsequent impact.

\subsection{Non-Parametric Spearman Correlations}

For the investigation of the correlations, the scores factors (average of all responses given to items) of each dimension were calculated. Professional function was recorded as a categorical variable ( $0=$ Auxiliary personnel; $1=$ All others) (Table 9$)$.

There remained negative correlation $(\mathrm{r}=-0.180)$ with the dimension "expectancy". Personal assistants have higher expectations to the distance learning courses programs generate motivation to carry out the work. Participants were positively realized that they have the opportunity to conduct distance learning courses.

It's observed, although according to the data obtained, there is a moderate positive correlation among all the surveyed motivation dimensions. There was no statistically significant correlation with performance measurement at work.

Individuals who consider motivator that the Organization offer distance learning courses also consider there is recognition and reliability front of the gathered from efforts in its realization. The support dimension generates positive effects on job enrichment dimension $(r=0.51)$, indicating that the working conditions are able to favorably influence the perception of applicability of the content learned in the distance courses. It was identified a significant positive correlation between the dimensions "support" and "expectation" $(r=0.47)$, and "support" and "recognition" $(r=0.39)$. Data suggest that the expectation of the learner can have a possible effect on their perception of the organizational support.

Table 9. Non-parametric spearman correlation between all related dimensions.

\begin{tabular}{cccccc}
\hline & Support & Expectancy & $\begin{array}{c}\text { Social } \\
\text { Recognition }\end{array}$ & Reliability & $\begin{array}{c}\text { Job design } \\
\text { enrichment }\end{array}$ \\
\hline Factor Scores Support & 1 & & & \\
Expectancy & $0.474^{* *}$ & 1 & & \\
Social Recognition & $0.349^{* *}$ & $0.602^{* *}$ & 1 & 1 & \\
Reliability & $0.243^{* *}$ & $0.581^{* *}$ & $0.486^{* *}$ & $0.198^{*}$ & 1 \\
\hline Job Design Enrichment & $0.512^{* *}$ & $0.310^{* *}$ & $0.384^{* *}$ & 0. & \\
\hline
\end{tabular}

Notes: ${ }^{\star}$ Significant at $p<0.05 .{ }^{*}$ Significant at $p<0.01$. 
The perception of the learner increases when the expectation and support dimensions increase. It can be argued that if the distance course is aligned to personal interests and opportunities within the organization, it would ensure greater commitment, effort and persistence. The dedication, probably, would result in significant learning gains, making it a positive and transformative experience with learners.

The participants in this study consider that a distance learning programs is able to generate effects on performance, especially through the dimension "enrichment job design". We hypothesized that some cultural factors and the dimension scale "support" may have generated some kind of influence, since the support of colleagues tend to be fundamental for the individual to apply at work what he has learned.

\section{Discussion}

The results showed the importance of social context apprentice in the effectiveness of their learning. According to Baghdadi (2011) and Fleming and Baume (2006) an environment to support learning, based on planned distance courses based on the characteristics of learners, is essential to effective learning. These features are capable of generating impact on performance routines after performing of the distance learning courses.

The student should be able to study independently, without the physical presence of the teacher as a facilitator of learning. This result meets the founds of Kennedy (2014), when the researcher found that the autonomy of the student is directly related to its capacity for analysis, synthesis and organization of their routine studies. According to Chen, Magoulas and Dimakopoulos (2005), we found that the habits of the distance students must be considered in the planning of these courses. Their styles and learning strategies should be considered. Characteristics of massive open online courses.

Expectations for learn increase when you realize a real chance of applying the content learned in performance of labour routines (Steers, Monday, \& Shapiro, 2004; Zawacki-Richter, Bäcker, \& Vogt, 2009). Personnel characteristics and dispositional variables, as style cognitive and motivation to learning and transfer must be considered (Fleming \& Baume, 2006; Riding \& Sadler-Smith, 1997). Other important variables, as Gagné and Deci (2005) pointed (motivation is an individual perspective, according to students' interests), the influence of managerial leadership styles on motivation (Nijstad, Berger-Selman, \& De Dreu, 2012; Yang \& Mossholder, 2010; Korek, Felfe, \& Zaepernick-Rothe, 2010) and the role of the support provided by colleagues and the working group in generating motivation (Korek, Felfe, \& Zaepernick-Rothe, 2010) were found in our empirical research.

The higher motivation of the learner generates effects on their performance (McMurray, Pirola-Merlo, Sarros, \& Islam, 2010). The perception of support to learning from colleagues and management is extremely important to the impact of instructional action in work routines. The employees must be encouraged to apply their competences and expertise acquired in the course in their work routines. Recognition through explicit praise especially by the leader should happen. The learner must have time available 
to devote to complete the course. The planning of organizational skills is the key to maximize the performance of the student (Stanton \& Harkness, 2014).

\section{Conclusions}

This study aimed to identify the motivational profile by learners' employees of a Brazilian Organization for learning via distance education programs. It's believed that this objective was fully achieved, since the forming dimensions of a motivational profile have been identified, and these signaled the strategic nature of distance education modality in promoting student learning.

It was recognized here the powerful potential of distance education in the training of Brazilian workers, provided like as students of this modality of learning. We discussed how, in fact, students perceive their learning as significant, emphasizing its integrative character to broader organizational interests.

The results indicate that the distance education programs need to develop systematic methodologies and appropriate theoretical scope, relativizing the role of students, tutors and student's learning context. Further studies are needed to relate individual variables and learning outcomes in distance education, testing the relationship of variables relevant to the theoretical/empirical advances in the area.

Similarly, studies are needed relating organizational variables and results of distance education, checking the influence of environmental or contextual factors in the process of distance learning. It's relevant to researches in the area to identify factors or elements that facilitate distance education, especially related to the planning, preparation and organization of courses and adapt them to the reality of organizations. Studies to aim what are the interests, needs of the students should be done. Dispositional characteristics (attitudes towards distance education) should also be performed in order to identify expectations and motivations of the learner.

These studies would be aimed also to research how distance education characteristics distinguish it from other forms of teaching and learning in organizations, which may cause benefits to organizations and, in particular, to education as a whole. As research agenda, it's suggested to conduct more empirical research in education distance, based on the empirical results of this research, specifically contemplating psychosocial support variables to learning climate for transfer and impact of learning on the job. It is also suggested to:

1) Analyze the social interactions in the workplace and its relationship with the encouragement of learning, especially of managers;

2) Analyze not only learned through online training but also through informal learning at work;

3) Apply the motivational profile instrument to learners who work in different organizational environments;

4) Investigate the relationship of the variables "culture of continuous learning", "learning organization", support learning and impact of learning at work;

5) Add other support items in the motivational profile measure, as the presence of 
social networks, portals, blogs and tutors;

6) Evaluate the relationship between learning strategies variables (diversification), study habits, reactions (to the instructional content, tutoring, and instructional procedures) and support learning in order to verify which of these variables explain better impact of learning at work;

7) Investigate which aspects of psychosocial support, especially from peers and supervisors, inhibit innovative behaviors in learning and impact of new competences on the job, being able to create even a specific instrument for measuring situational constraints performance or lack support;

8) Analyze results and the applicability of the learned content, considering that the planning should be directed to people who effectively need to know all content;

9) Investigate what conditions, components or elements of the organizational environment, not investigated in this work, are conducive to the application of content learned in the training context and informal learning situations;

10) Analyze the effect of the involvement of peers and supervisors at the stage of evaluation training needs on the conditions of transfer and impact of new competences on the job;

11) Verify the influence of psychosocial variables on learning, especially in the informal process of learning and apply new knowledge and competences to the workplace;

12) Deepen research about distance education variables, especially to identification the profile of who is the user of distance education, optimizing the process of and learning and impact;

13) Investigate the influence of other macro level variables, such as a culture of continuous learning and climate for creativity, stimulating learning and the use of new competences at work;

14) Identify which personal and organizational variables stimulate the acquisition, retention and subsequent generalization of competences and abilities acquired in the distance education programs, and relate them to the key concept of this work, motivational profile;

15) Analyze the role of tutors in the process of teaching and learning in distance education programs;

16) Analyze the influence of learning needs assessment on the expected results and motivational profile.

\section{Acknowledgements}

The authors would like to acknowledge the financial support provided by the Brazilian National Scientific and Technological Development Council (CNPq/Brazil).

\section{References}

Baghdadi, Z. (2011). Best Practices in Online Education: Online Instructors, Courses, and Administrators. Turkish Online Journal of Distance Education, 12, 109-117. 
Bozkurt, A., Akgun-Ozbek, E., Yilmazel, S., Erdogdu, E., Ucar, H., Guler, E., Sezgin, S., \& Aydin, C. (2015). Trends in Distance Education Research: A Content Analysis of Journals 2009-2013. The International Review of Research in Open and Distributed Learning, 16, 330-363. http://www.irrodl.org/index.php/irrodl/article/view/1953/3192 http://dx.doi.org/10.19173/irrodl.v16i1.1953

Bowen, W. G., \& Ithaka, S. (2012). Interactive Learning Online at Public Universities: Evidence from Randomized Trials. Ithaka S+ R. http://mitcet.mit.edu/wp-content/uploads/2012/05/BowenReport-2012.pdf

Brown, B. W., \& Liedholm, C. E. (2004). Student Preferences in Using Online Learning Resources. Social Science Computer Review, 22, 479-492. http://dx.doi.org/10.1177/0894439304268529

Bulfin, S., Pangrazio, L., \& Selwyn, N. (2014). Making "MOOCs": The Construction of a New Digital Higher Education within News Media Discourse. International Review of Research in Open and Distributed Learning, 15, 290-305. http://dx.doi.org/10.19173/irrodl.v15i5.1856

Chen, S. Y., Magoulas, G. D., \& Dimakopoulos, D. (2005). A Flexible Interface Design for Web Directories to Accommodate Different Cognitive Styles. Journal of the American Society for Information Science and Technology, 56, 70-83. http://dx.doi.org/10.1002/asi.20103

Dirr, P. J. (2003). Distance Education Policy Issues: Towards 2010. In M. G. Moore, \& W. G. Anderson (Eds.), Handbook of Distance Education (pp. 461-480). New Jersey: Lawrence Erlbaum Associates, Inc.

Fleming, N., \& Baume, D. (2006). Learning Styles Again: VARKing up the Right Tree! Educational Developments, 7, 4-7.

Gagné, M., \& Deci, E. L. (2005). Self-Determination Theory and Work Motivation. Journal of Organizational Behavior, 26, 331-362. http://dx.doi.org/10.1002/job.322

Gasevic, D., Kovanovic, V., Joksimovic, S., \& Siemens, G. (2014). Where Is Research on Massive Open Online Courses Headed? A Data Analysis of the MOOC Research Initiative. The International Review of Research in Open and Distributed Learning, 15, 134-176.

http://www.irrodl.org/index.php/irrodl/article/view/1954

http://dx.doi.org/10.19173/irrodl.v15i5.1954

Grant, A. M., \& Sumanth, J. J. (2009). Mission Possible? The Performance of Prosocially Motivated Employees Depends on Manager Trustworthiness. Journal of Applied Psychology, 94, 927-944. http://dx.doi.org/10.1037/a0014391

Guerrero, S., LaPalme, M. E., \& Seguin, M. (2015). Board Chair Authentic Leadership and Nonexecutives' Motivation and Commitment. Journal of Leadership \& Organizational Studies, 22, 88-101. http://dx.doi.org/10.1177/1548051814531825

Hackman, J. R., \& Oldham, G. R. (1976). Motivation through the Design of Work: Test of a Theory. Organizational Behavior and Human Performance, 16, 250-279.

Hanna, D. (2003). Eleven Strategic Changes for Higher Education. Educause Review, 38, 25-34.

Hew, K. F., \& Cheung, W. S. (2014). Students' and Instructors' Use of Massive Open Online Courses (MOOCs): Motivations and Challenges. Educational Research Review, 12, 45-58. http://dx.doi.org/10.1016/j.edurev.2014.05.001

Hoic-Bozic, N., Mornar, V., \& Boticki, I. (2009). A Blended Learning Approach to Course Design and Implementation. EEE Transactions on Education, 52, 19-30.

Jacoby, J. (2014). The Disruptive Potential of the Massive Open Online Course: A Literature Review. Journal of Open, Flexible and Distance Learning, 18, 73-85.

Jong, T. (2010). Cognitive Load Theory, Educational Research, and Instructional Design: Some 
Food for Thought. Instructional Science, 38, 105-134.

http://dx.doi.org/10.1007/s11251-009-9110-0

Jordan, K. (2014). Initial Trends in Enrolment and Completion of Massive Open Online Courses. International Review of Research in Open and Distributed Learning, 15, 133-160.

http://dx.doi.org/10.19173/irrodl.v15i1.1651

Kennedy, J. (2014). Characteristics of Massive Open Online Courses (MOOCs): A Research Review, 2009-2012. Journal of Interactive Online Learning, 13, 1-16.

Korek, S., Felfe, J., \& Zaepernick-Rothe, U. (2010). Transformational Leadership and Commitment: A Multilevel Analysis of Group-Level Influences and Mediating Processes. European Journal of Work and Organizational Psychology, 19, 364-387. http://dx.doi.org/10.1080/13594320902996336

Lloyd, S. A., \& Robertson, C. L. (2012). Screencast Tutorials Enhance Student Learning of Statistics. Teaching of Psychology, 39, 67-71. http://dx.doi.org/10.1177/0098628311430640

McMurray, A. J., Pirola-Merlo, A., Sarros, J. C., \& Islam, M. M. (2010). Leadership, Climate, Psychological Capital, Commitment, and Wellbeing in a Non-Profit Organization. Leadership \& Organization Development Journal, 31, 436-457. http://dx.doi.org/10.1108/01437731011056452

Meyer, J. P., Stanley, D. J., Herscovitch, L., \& Topolnytsky, L. (2002). Affective, Continuance, and Normative Commitment to the Organization: A Meta-Analysis of Antecedents, Correlates, and Consequences. Journal of Vocational Behavior, 61, 20-52.

http://dx.doi.org/10.1006/jvbe.2001.1842

Nijstad, B. A., Berger-Selman, F., \& De Dreu, C. K. W. (2012). Innovation in Top Management teams: Minority Dissent, Transformational Leadership, and Radical Innovations. European Journal of Work and Organizational Psychology, 23, 310-322.

http://dx.doi.org/10.1080/1359432X.2012.734038

Norasmah, O., \& Mohd Hasril, A. (2010). Different Perspectives of Learning Styles from VARK Model. Procedia-Social and Behavioral Sciences, 7, 652-660.

http://dx.doi.org/10.1016/j.sbspro.2010.10.088

Oblinger, D. G., \& Rush, S. C. (2003). The Involvement of Corporations in Distance Education. In M. G. Moore, \& W. G. Anderson (Orgs.), Handbook of Distance Education (pp. 587-600). Mahwah, New Jersey: Lawrence Erlbaum Associates Publishers.

O'Connor, K. (2014). MOOCs, Institutional Policy and Change Dynamics in Higher Education. Higher Education, 68, 623-635. http://dx.doi.org/10.1007/s10734-014-9735-Z

Perna, L. W., Ruby, A., Boruch, R. F., Wang, N., Scull, J., Ahmad, S., \& Evans, C. (2014). Moving through MOOCs: Understanding the Progression of Users in Massive Open Online Courses. Educational Researcher, 43, 421-432. http://dx.doi.org/10.3102/0013189X14562423

Riding, R. J., \& Sadler-Smith, E. (1997). Cognitive Style and Learning Strategies: Some Implications for Training Design. International Journal of Training and Development, 1, 199-208. http://dx.doi.org/10.1111/1468-2419.00020

Stanton, J. M., \& Harkness, S. S. J. (2014). Got MOOC? Labor Costs for the Development and Delivery of an Open Online Course. Information Resources Management Journal, 27, 14-26. http://dx.doi.org/10.4018/irmj.2014040102

Steers, R. M., Monday, R. T., \& Shapiro, D. L. (2004). Introduction to Special Topic Forum: The Future of Work Motivation Theory. The Academy of Management Review, 29, 379-387. http://dx.doi.org/10.2307/20159049

Veletsianos, G., \& Sheperdson, P. (2016). A Systematic Analysis and Synthesis of the Empirical MOOC Literature Published in 2013-2015. The International Review of Research in Open and 
Distributed Learning, 17, 198-221. http://dx.doi.org/10.19173/irrodl.v17i2.2448

Vroom, V. H. (1964). Work and Motivation. San Francisco, CA: Jossey-Bass.

Walumbwa, F., Avolio, B., Gardner, W., Wernsing, T., \& Peterson, S. (2008). Authentic Leadership: Development and Validation of a Theory-Based Measure. Journal of Management, 34, 89-126. http://dx.doi.org/10.1177/0149206307308913

Watkins, R., \& Kaufman, R. (2003). Strategic Planning for Distance Education. In M. Moore (Ed.), Handbook of American Distance Education. Mahwah, NJ: Lawrence Erlbaum Associates.

Wendelien, V. E., \& Henk, T. (1996). Vroom's Expectancy Models and Work-Related Criteria: A Meta-Analysis. Journal of Applied Psychology, 81, 575-586.

http://dx.doi.org/10.1037/0021-9010.81.5.575

Yang, J., \& Mossholder, K. W. (2010). Examining the Effects of Trust in Leaders: A Bases-andFoci Approach. Leadership Quarterly, 21, 50-63. http://dx.doi.org/10.1016/j.leaqua.2009.10.004

Zawacki-Richter, O., Bäcker, E., \& Vogt, S. (2009). Review of Distance Education Research (2000 to 2008): Analysis of Research Areas, Methods, and Authorship Patterns. The International Review of Research in Open and Distributed Learning, 10, 21-50.

Submit or recommend next manuscript to SCIRP and we will provide best service for you:

Accepting pre-submission inquiries through Email, Facebook, LinkedIn, Twitter, etc.

A wide selection of journals (inclusive of 9 subjects, more than 200 journals)

Providing 24-hour high-quality service

User-friendly online submission system

Fair and swift peer-review system

Efficient typesetting and proofreading procedure

Display of the result of downloads and visits, as well as the number of cited articles

Maximum dissemination of your research work

Submit your manuscript at: http://papersubmission.scirp.org/

Or contact ce@scirp.org 